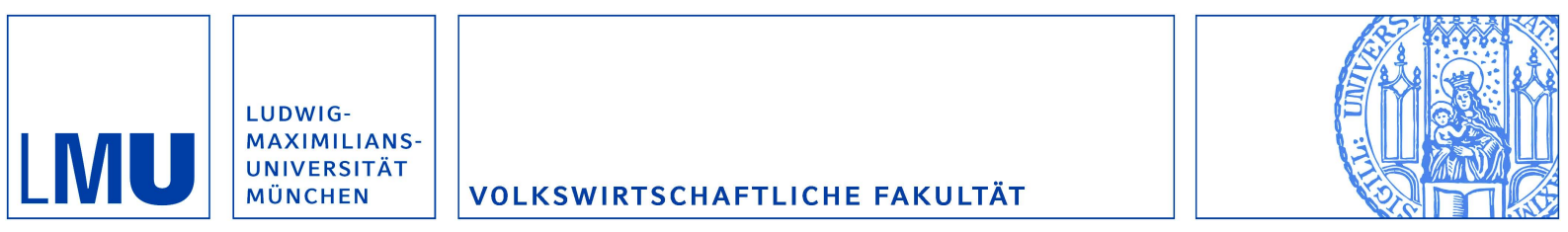

Komlos, John; Hau, Michel und Bourginat, Nicolas: An Anthropometric History of Early-Modern France

Munich Discussion Paper No. 2003-10

Department of Economics

University of Munich

Volkswirtschaftliche Fakultät

Ludwig-Maximilians-Universität München

Online at https://doi.org/10.5282/ubm/epub.54 


\title{
The Anthropometric History of Early-Modern France
}

\author{
John Komlos, University of Munich \\ In collaboration with Michel Hau and Nicolas Bourguinat, University of Strasbourg
}

French scholars have been in the forefront of anthropometric research ever since Count de Montbeillard recorded his son's height profile between 1759 and $1777 .{ }^{1}$ Similarly, Louis René Villermé was the first statistician of public health in the early $19^{\text {th }}$ century, who noted that the height of a population correlated positively with the productivity of the soil: ,physical stature is greater, and men grow faster, the wealthier is the country; in other words, misery produces short people, and delays the achievement of final height. “2 In our own time, Emmanuel Le Roy Ladurie, carried on the tradition by being the first historian to examine systematically the geographic variation and the socio-economic correlates of human height in $19^{\text {th }}$ century France. In a series of publications beginning in 1969 he showed, that the physical stature of recruits born in the late 1840 s correlated positively with their education and wealth. Illiterates averaged $164.3 \mathrm{~cm}$, while those able to read and write were $1.2 \mathrm{~cm}$ taller. Presumably literate men came from wealthier families, and spent more time at education and less at work than did illiterates. ${ }^{3}$ Although after a hiatus of some two decades considerable research on French $19^{\text {th }}$ century heights continued in the 1990s, ${ }^{4}$ the anthropometric history of France of the Ancien Régime remains completely uncharted territory.

In order to fill this gap in our knowledge of the biological standard of living in France at this crucial juncture of its history, a sample of 38,700 observations was extracted from archival military documents from the reigns of Louis XV and Louis XVI. ${ }^{5}$ These are the earliest written records on human physical stature hitherto analyzed. Information available on the soldiers include age, date on which the military registers were started, date of enlistment, height (in pied, pouce, and ligne; hereafter referred to as French inches [F.i.], ${ }^{6}$ locality of the soldier's birth (name of village or town and province), ${ }^{7}$ name of the company, in some cases the profession of the soldier and that of his father, and archival number of the registers. ${ }^{8}$ The sample was taken from 80 
archival groups. ${ }^{9}$ About a quarter of the recruits in the sample are teenagers, and about a half were in their twenties at the time they were measured (Table 1). 14 percent of the records have information on the father's profession and 11 percent on the soldier's occupation prior to enlistment. ${ }^{10}$ Height profiles indicate that the recruits reached their final height at age 23 ; hence, those at or above this age are considered adults. A very large proportion of the recruits (53\%) were recorded as having been born in towns, although the urban share of the French population was at most 14 percent in $1750 .{ }^{11}$ This leads to the inference that the recorded town of provenance was not to the actual municipality itself, but must have included its environs. Otherwise, such a large discrepancy in spatial distribution would be impossible to explain. Birth cohorts in the sample extend from 1650 to 1770 , who enlisted between 1671 and 1786 . That the recruits were measured with some care is evinced by the fact that the height of only 58.4 percent of the recruits was given as an integer.

\section{Preliminary Statistical considerations}

The existence of a minimum height requirement for acceptance into the military implies that our data are not a random sample from the population of French men. Hence, statistical procedures must be used to overcome this bias. A reliable technique is truncated regression analysis (TOLS), which has been found in simulation exercises to yield accurate estimates of trends. ${ }^{12}$ TOLS is based on ordinary least squares regression after eliminating all observations below the largest of the minimum height requirements (MHRs); the distribution of heights is unbiased to the right of this point. Though the conditional coefficient estimates obtained by TOLS are biased, both the signs of the coefficients, and their relative ordering are unbiased. This is crucial, because the coefficients of the truncated regressions, can be converted into true population means. ${ }^{13}$ Hence, unless otherwise noted, the estimated mean heights reported here are not the actual heights of the soldiers themselves, but those of the corresponding population of able-bodied men from whom the recruits were drawn. 
The distributions of heights by enlistment dates indicates that the largest of the MHR in effect during the period under consideration was 62 F.i. (1678 mm) (Figure 1). ${ }^{14}$ We discard the observations smaller than this MHR, or to be on the conservative side, we actually discard the observations smaller than 61.75 , assuming that those who were just slightly below the MHR were probably allowed to slip through, i.e., their height was probably rounded up to the nearest whole inch. ${ }^{15}$ By eliminating observations below 61.75 F.i. the size of the working data set is reduced to $28,000 .{ }^{16}$ Soldiers in a number of special companies $(\mathrm{N}=2,771)$, such as the grenadiers (grenade throwers), had heights well above average, and hence a dummy variable was introduced in order to control for the height of men serving in these companies. ${ }^{17}$

We investigated if the measurement techniques or recruiting selectivity changed sufficiently over time to affect substantially the recorded height of the recruits, by using the decade of enlistment as an independent variable in the TOLS regressions. ${ }^{18}$ If, for example, those born in the 1750s and recruited in the 1770s would turn out to be taller than those who, though born in the same decade, were recruited in the 1780s, then one might well infer that that difference was due to enlistment or measurement effects. A hypothesis to be tested is whether recruits were initially measured with their boots on, and subsequently without. In that case, we would find an abrupt, and once-and-for-all decline in the coefficient of the enlistment variable. However, we do not find such pattern that could be attributed to changes in measurement technique. Instead, we find that these effect fluctuates over time and are inconsistent among youth and adults (Table 3). The adult coefficient increased substantially toward the end of the period under consideration. Though this might be interpreted as supply or demand effects, we are hesitant to do so. While it is imaginable that somewhat taller men entered the army during the economic downturns just before the revolution, the inconsistencies across age groups, leads us not to attribute much significance to this result, and in subsequent analysis we do not include the enlistment variable. In any event, it is noteworthy that the enlistment effect varies over time, 
because that implies that the result was not likely to have been caused by systematic changes in the measuring practices. ${ }^{19}$

\section{The overall trend in the height of French men}

We first estimate adult heights annually using TOLS regression in which dummy variables were entered for the date of birth. Subsequently, five-year-moving averages were calculated from these annual values. The cycles and trends are averages for all of France, though the level of the estimates is standardized for the Ile de France. ${ }^{20}$ The results indicate vividly that the French population was extremely short in the $17^{\text {th }}$ century: around $1617 \mathrm{~mm}$ (Table 4 and Figure 2). Such average adult heights were not to be seen in France again. Furthermore, there is evidence of considerable short-term fluctuations during the course of the second half of the $17^{\text {th }}$ century. ${ }^{21}$ An amazingly rapid recovery began in 1695 after the severe demographic crisis of 1693-94, and extended until 1706, with an average increase in heights of some $3.2 \mathrm{~mm}$ per annum for a period of 12 years. The relatively high plateau, at $1655 \mathrm{~mm}$, was maintained for the subsequent 12 years (1706-1716), but was reversed beginning with 1717 when a decline in physical stature began lasting until 1724 , though heights remained well above $17^{\text {th }}$ c. levels. In fact, even at the troughs of 1724 and 1760 , heights in the $18^{\text {th }}$ century remained well above those of the $17^{\text {th }}$ century. A persistent cyclical upward trend began in the mid-1720s, that lasted with minor interruptions until 1740 , reaching and even exceeding the early- $18^{\text {th }}$-century maximum. Thereafter ensued a marked diminution in physical stature, that lasted until 1761, with a possible reversal of the downward trend in 1762 and 1763, the last years for which data on adults are available. These basic results were corroborated in a number of different ways we analyzed the data. ${ }^{22}$

We next use quinquennial dummy variables for the date of birth in a TOLS regression in order to compare the adult series to the height of the youth (Figure 3). A quenquennial estimates for youth include ages 16-22 but the level is standardized on 22-year-old soldiers of the Ile de France (Figure 3). The correlation between the adult and youth estimates is best when the youth height series is lagged by five years. ${ }^{23}$ This shifts the overlap between the nutritional experiences 
of the adults and youth toward the very end of the growth process. ${ }^{24}$ According to the results there was an upward trend also in the height of youth that peaked in the early 1740 s, to decline thereafter. There were considerable short-term fluctuations. The major departure from the adult pattern is discernable only in 1705-9 when the nutritional status of the youth decreased while that of the adults does not. ${ }^{25}$

\section{Spatial Patterns}

Throughout the period under consideration, heights were shortest in the center of the country from Auvergne to Brittany, with heights increasing outwardly in a kind of semicircle toward the periphery. The tallest men in the sample were born around the Mediterranean, in the North, and in the Northeast (Map 1). The regional pattern was similar in the $17^{\text {th }}$ century, though the increase from south to north was more clearly defined, and in the Mediterranean only Provence had men among the taller categories (Map 2). The increase in height at the end of the $17^{\text {th }}$ century was quite general throughout France. In more than half of all gouvernements the increase in height was in excess of $3 \mathrm{~cm}$ between the $17^{\text {th }}$-century trough and the early- $18^{\text {th }}$-century apex (Figure 4 ). However, even at the peak, heights in the center of the country were at relatively low level of 165 $\mathrm{cm}^{26}$ (Figure 5), with the regional pattern remaining more-or-less unchanged. The difference between the height of men born in Hainaut and those born in Auvergne was a substantial $4 \mathrm{~cm}$.

In order to ascertain spatial variations in the trends and cycles in physical stature, we estimate heights at the regional level. Because of disaggregation, there are smaller number of observations available; hence we use decadal averages as the basis of comparison. The cycles found above were, in the main, quite congruous throughout the country, albeit with some deviations delineated below. Nutritional status in the Southwest ${ }^{27}$ tracked the French average very closely until 1730 and fell below it thereafter to some extent, while in the Mediterranean ${ }^{28}$ region $^{2}$ heights tended to be consistently above average (Figure 6). The height advantage of the Mediterranean region over the Southwest was at least two $\mathrm{cm}$ during most of the $18^{\text {th }}$ century. Heights in the Center, expanding from Lyon to Brittany also followed the average fluctuations in 
the country. This region was, in turn, divided into three sections, East-Center, West-Center and Center-Center. In the West-Center ${ }^{29}$ and in the Center-Center ${ }^{30}$ regions heights were well below average throughout the observation period, and were correlated sufficiently to be combined for purposes of analysis (Figure 7). In contrast, soldiers from the East-Center ${ }^{31}$ were consistently very near to the French average. So were, until the 1740s, the men from the three provinces of Normandy, Ile de France and Champagne, referred to as the Mid-North. The major distinguishing feature of their height pattern is that heights of men born in the 1750s were well above average. Finally, we combine the estimates of the Northeast provinces (Franche Comte, Alsace, and Lorraine) and of the North (Picardie, Artois, Hainaut, and Flanders) which had the tallest men in France throughout most of the period (Figure 8). In sum, the analysis of the trend at the regional level indicates that there was considerable correlation among them, even though there were substantial differences in the level of heights themselves. The tallest men were found in the North, Northeast, and the Mediterranean and the shortest in the Center and West-Center.

We next divide France into "tall" provinces (North, Mid-North, Northeast ${ }^{32}$ and Mediterranean) on the one hand, and "short" provinces on the other (Center, West-Center, Southeast) (Figure 9). It is noteworthy that the two estimates are practically parallel to one another throughout the observation period with a difference in favor of the "tall" provinces of some 2.3 $\mathrm{cm} .{ }^{33}$ There is a high correlation between the height of youth and those of adults at the provincial level. We do not present these graphs here because of space considerations. Youth from the tall provinces were also much taller than their counterparts from the short provinces (Figure 10). Urbanization had practically no systematic effect on heights anywhere except in Paris. ${ }^{34}$ The coefficient of the log of the town size variable was invariably small and insignificant at the. ${ }^{35}$ This is the case at the provincial, regional, and at the country-wide levels. For both the short and tall provinces adult heights were almost identical for rural and $\mathrm{urban}^{36}$ men (Figures 11 and 12). As stated in the introduction, it is highly probable that the town of provenance designations were not correctly recorded by the recruiting officers and that, except for Paris, soldiers from the 
vicinity of a town were probably just conflated with the town populations themselves. The only major divergence from the general trend is among soldiers from Paris, who were markedly shorter than average between the $1690 \mathrm{~s}$ and $1730 \mathrm{~s}^{37}$ (Figure 12).

\section{Heights and Occupation}

Height differences of adults by occupation is analyzed using the father's occupation if available. If unavailable, we used the soldier's occupation as a proxy of the family circumstances during the soldier's youth. ${ }^{38}$ The results correspond to the social hierarchy of the period: textile workers were about $36 \mathrm{~mm}$ shorter than soldiers with an upper class background (Figure 13). ${ }^{39}$ Propinquity to food conferred an advantage beyond what one would expect on the basis of socio-economic status. Occupations related to the processing of food products, such as butchers and bakers were $7 \mathrm{~mm}$ taller than skilled craftsmen, and were as tall as middle-class soldiers. This points to the advantages of the propinquity to food for nutritional status during childhood and adolescence.

\section{Heights and Exogenous Influences}

We explore the effect of two influences on French heights for which data are extant: wheat prices as a proxy for agricultural conditions, and climate as a measure of the environmental situation. Prices reflect the relative scarcity of foods in general, and should therefore correlate inversely with consumption and, thus, with heights. In turn, weather conditions can effect physical stature in two ways; it can effect it directly through influences on the basal metabolic rate, i.e., the amount of nutrients the body needs to maintain its biological functions, such as keeping body temperature at the appropriate level. An increase in the temperature of the environment implies that the human organism does not need to use as much of its nutrient intake to maintain body temperature and hence more nutrients remain available for the growth process. ${ }^{40}$ In addition, climate also has an indirect effect on human physical stature insofar as it had a proximate effect on agricultural production under pre-industrial conditions. Favourable summer temperatures, in particular, brought about larger harvests, and greater output of hay and pasture grasses. These, in 
turn, would have affected the production of both meat and dairy products on which data are generally not extant for this period. ${ }^{41}$ In addition, warmer weather presumably also had a positive impact on the size of livestock, insofar as the amount of nutrients they themselves consumed could be used for their growth, rather than for maintaining body temperatures. Hence, the influence of climate on human physical stature is theoretically quite plausible, and has been found in other populations as well. ${ }^{42}$

The French height data support these theoretical considerations. We find a quite pronounced negative correlation between height of youth (with a 5-year lag) and of cereal prices at Beauvais ${ }^{43}$ (Figure 14). A similar negative correlation between height and grain prices has been documented for other countries. ${ }^{44}$ In addition, a positive correlation is found between both Swiss ${ }^{45}$ and English temperatures and heights ${ }^{46}$ (Figures 15-17). The correspondence, except during 172024 is quite remarkable, given that the heights and temperature readings are not for the same geographic entity, even if, in the case of Switzerland, they are for a contiguous one. ${ }^{47}$ The only temperature data available for France for the period is for Paris for the years $1675-1715{ }^{48}$ The positive relationship between physical stature and climatic conditions is again impressive (Figure 18). Rainfall too, particularly in the autumn, had a negative effect on heights (Figure 18), insofar as dryer summers and autumns were beneficial to the harvest, because too much rain destroyed crops. ${ }^{49}$ Hence, the influence of climatic conditions and of prices on physical stature is evident. These basic results are confirmed in a multiple regression framework, even if the independent variables are not always significant due to multicollinearity. The F-statistic is nonetheless, significant, and the coefficients are of the right sign, and at least one of the independent variables is significantly different from zero (Table 5).

Without the collaborative evidence on the very substantial rise in temperatures in the early $18^{\text {th }}$ century, the very large increase in adult physical stature of almost $4 \mathrm{~cm}$ might well be considered with some incredulity for being unprecedented. ${ }^{50}$ Such rates of increase in human size have been observed only at the cessation of widespread famines due to a natural- or man-made 
catastrophes, or in cases when dietary supplements were introduced to improve the diet of a malnourished population. Evidently, the $17^{\text {th }}$ century were starving times for the majority of the French population, and the substantial improvement in weather conditions, including an increase in temperatures and a decline in summer and autumn rainfall, had an almost immediate ameliorating impact on their biological condition. ${ }^{51}$ Clearly, less calories were needed for the basal metabolic rates under such improving environmental conditions, and at the same time agricultural output must have increased in previously unmeasured ways, by affecting the output of meat and dairy products. These were hitherto unknown,- and perhaps even unimaginable - improvements in the human condition at the end of the Little Ice Age.

\section{International Comparisons and the Anthropometric History of the French Revolution}

Evidence on physical stature is unavailable for other European countries in the $17^{\text {th }}$ century, but by the time it does become available in the early- $18^{\text {th }}$ century the obtained patterns are highly synchronous with French height trends and cycles. The $18^{\text {th }}$-century peak is reached among the birth cohorts of the 1740s, in a large number of countries and regions, including England, Sweden, Hungary, and Bohemia and the trend thereafter is downward in most cases until the end of the century $^{52}$ (Figure 20). This is also the case for a number of other regions not depicted in Figure 20, such as Bavaria, Northern Italy, Lower Austria, Moravia, Galicia, Ireland, and Scotland. ${ }^{53}$ There can be no doubt at all that the French pattern fits perfectly into the general anthropometric history of $18^{\text {th }}$-century Europe.

It is interesting in this regard to consider the developments of French nutritional status during the generation prior to the outbreak of the Revolution in 1789. Was the threat of a Malthusian crisis unusually severe in France? Although, we have not collected evidence for the revolutionary period itself, there do exist data on the height of 20-21 year-old conscripts of the Napoleonic period. ${ }^{54}$ The average height of recruits of this age bracket born at the end of the century was $1636 \mathrm{~mm}$. This value is on a solid evidential basis, insofar as it is based on all soldiers who served in the military. We can estimate adult height of the birth cohorts of the 1780s, 
1790s and 1800s as being about $1 \mathrm{~cm}$ beyond those of the 20 - and 21-year olds or about $1646 \mathrm{~mm}$ (Figure 20). The comparison implies that, though adult heights did decline to some degree during the generation prior to the Revolution, the diminution was by no means substantial. Actually, the deterioration in nutritional status in France was not at all more critical than in other parts of Europe. Though there were obvious signs of a threat of a Malthusian crisis, its severity was well within the European norm, and very far from being as precarious as it had been in the $17^{\text {th }}$ century. In addition to adults, we can examine the secular trend in the height of 20-and 21-year olds taken together, because these ages became the recruitment standard under Napoleon, which enables us to make comparisons with heights of the revolutionary period without resorting to adjustments for growth after age 20/21. We do obtain the same pattern among the 20-21 year olds as among the adults: there is a slight decline in the intervening decades, but the diminution in heights is practically identical to that obtained for Bohemian and Hungarian soldiers of the same age (Figure 21). The decline was by no means dramatic - heights decreased to the level prevailing in the 1750 s, and was dwarfed by the much greater social differences of the time between the students at the École Polytechnique, and those of the ordinary citizens of the Revolution. The students at the École enjoyed a $7 \mathrm{~cm}$ advantage over their lower-class brethren, though such social differences were rather common in Europe at the time.

Nonetheless, the lower levels of nutritional status do indicate that the French society was being challenged, as were the other European societies of the time, by the diminution in food availability per capita at mid-century. ${ }^{55}$ This ought not be disregarded, because the generation of the 1750 s with a lower nutritional status, were 30 - to 39 -years old at the outbreak of the revolution, and would certainly have participated in the associated upheavals. The nutritional deprivations they faced in childhood and adolescents might well have colored their perception of the Ancien Régime.

The slight rebound in heights of the birth cohorts of the 1760s (Figure 2, 3, and 21) enables us to infer that the nutritional crisis prior to the outbreak of the revolution was neither 
particularly prolonged nor hopelessly severe. Admittedly, the evidential basis is incomplete - for evidence is lacking on the birth cohorts of the 1770s, but it is, nonetheless, taken together, quite suggestive: the Malthusian crisis that was threatening all of Europe, and France in particular, was very far from being as overwhelming as it had been in the $17^{\text {th }}$ century. Though these were nodoubt adverse times, the nutritional status was not deteriorating rapidly and hopelessly in France, and there seems to have been sufficient buoyancy in the economy to overcome the cyclical nutritional downturn that started in the 1750s.

\section{Conclusion}

The height of the French male population born between circa 1660 and 1760 was estimated, on the basis of military records. The meaning of the "crisis of the $17^{\text {th }}$ century" gains a new dimension on the basis of this evidence. ${ }^{56}$ There were frequent demographic (and political) crisis in $17^{\text {th }}$ century Europe, some of which were of considerable severity. The famine of 1693 , for example, one of the worst to visit Western Europe since the Middle Ages, "turned France into a big, desolate hospital without provisions". ${ }^{57}$ In addition, the climatic conditions deteriorated considerably during the "Little Ice Age". Temperatures dropped, glaciers advanced, and agriculture did not thrive under such circumstances. Moreover, numerous military conflicts on the Continent brought about further devastation as well as economic dislocation. On the basis of the evidence unearthed in the French military archive it is now also evident that the crisis of the $17^{\text {th }}$ century also had an immense impact on the human organism itself. Not only did population size decline, but the physical size of the men living through those adverse times did as well, even to an unthinkable degree, - in response to these adverse economic and environmental circumstances. The height of the average adult Frenchmen was some $161.7 \mathrm{~cm}$ - a stature that was not recorded since then. This is one of the major findings of this investigation.

With the improvement in climatic conditions at the turn of the $18^{\text {th }}$ century, the human organism responded to an unprecedented degree, increasing in size by some $3.8 \mathrm{~cm}$ within a short span of 12 years. Thereafter the trends and cycles in physical stature were influenced not only by 
annual temperatures, but by grain prices, and rainfall as well. The physical stature of men increased until the birth cohorts of the 1740s, to decline thereafter, in keeping with the European norm, but the decline of the 1750 s was by no means unusually severe. Rather, it appears that the threat of a Malthusian crisis was mild by $17^{\text {th }}$-century standards, and its intensity in France was not at all more powerful than in other parts of Europe. France was obviously not suffering from a prolonged period of malnutrition brought about by stagnating agricultural conditions or economic depression as some scholars have argued in the past. ${ }^{58}$ Rather, on a per capita basis, the French economy probably grew as impressively in the $18^{\text {th }}$ century as did the British. ${ }^{59}$ Hence, he anthropometric evidence supports the notion that the French economic performance was not the fundamental cause of the political turmoil of the 1780s. The coming of the French Revolution cannot be explained on the basis of objective economic circumstances alone. That is not to say, that all was well. There were obvious signs of incredible social differences, which could have clearly fueled the political fires of rebellion. The height of the upper classes was well above those of the average Frenchman. It was as though the two social classes lived in different worlds, but, that, too, was the European norm of the time. In the final analysis, the evidence unearthed in the French military archives suggests that the events of 1789 was rooted more in perceptions, in ideology, and in political forces, than in objective economic circumstances. This is the second important finding of this investigation. 
Fig. 1. Distributions of the Height of French Soldiers (Rounded to the nearest half inch)

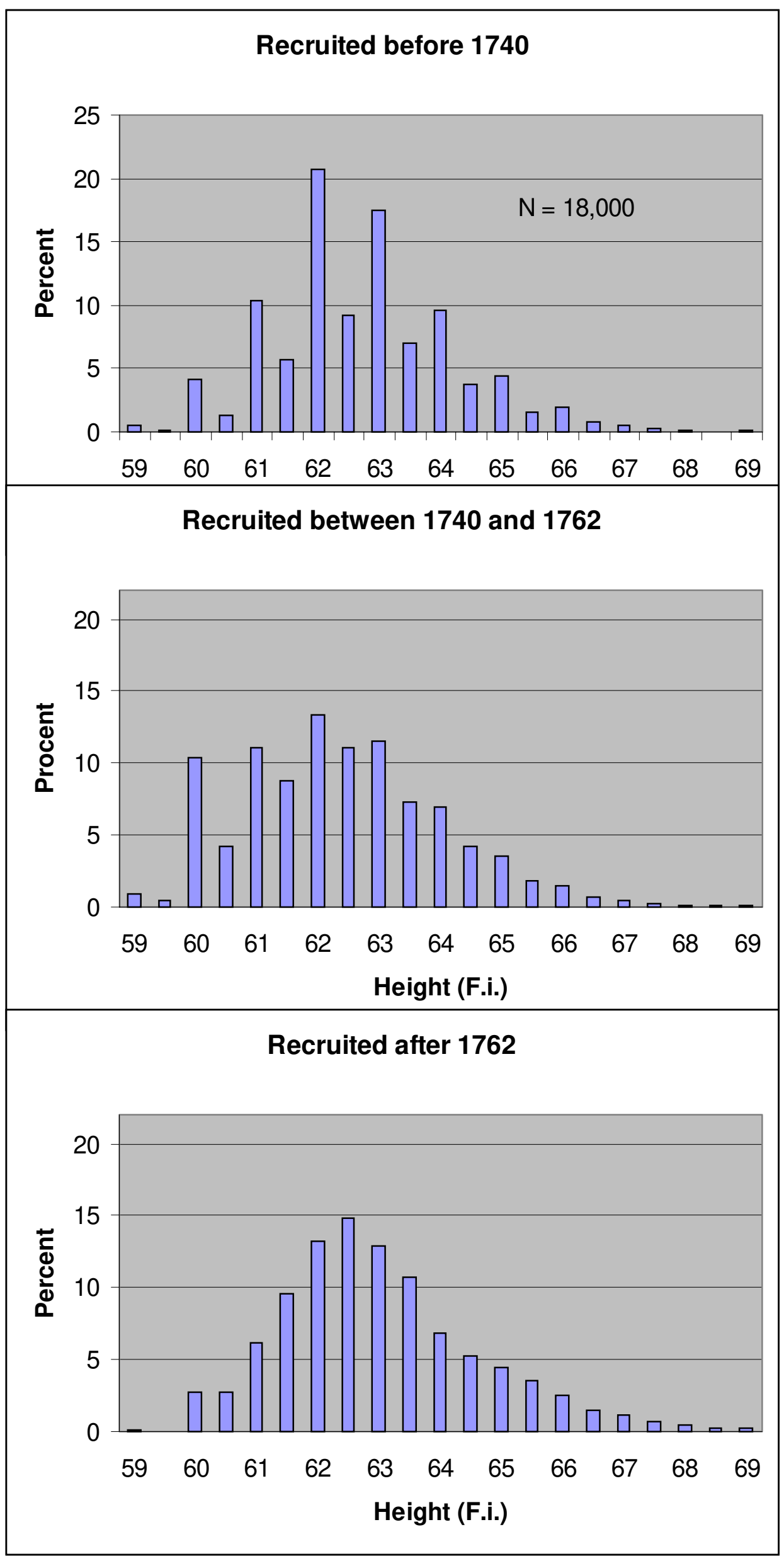


Fig. 2 Estimated Height of Adult French Men (mm)
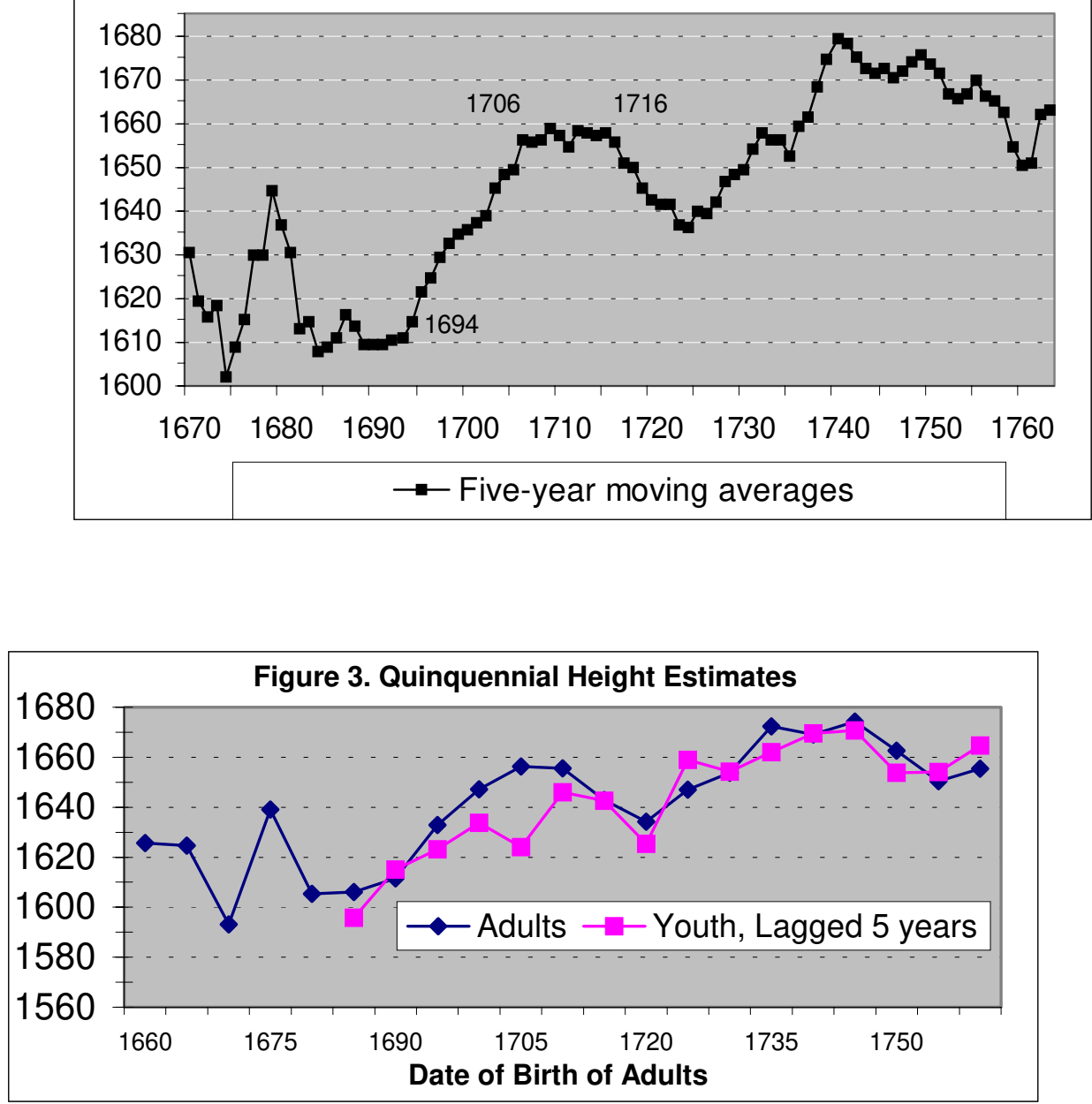
Map 1. Adult Height 1664-1763
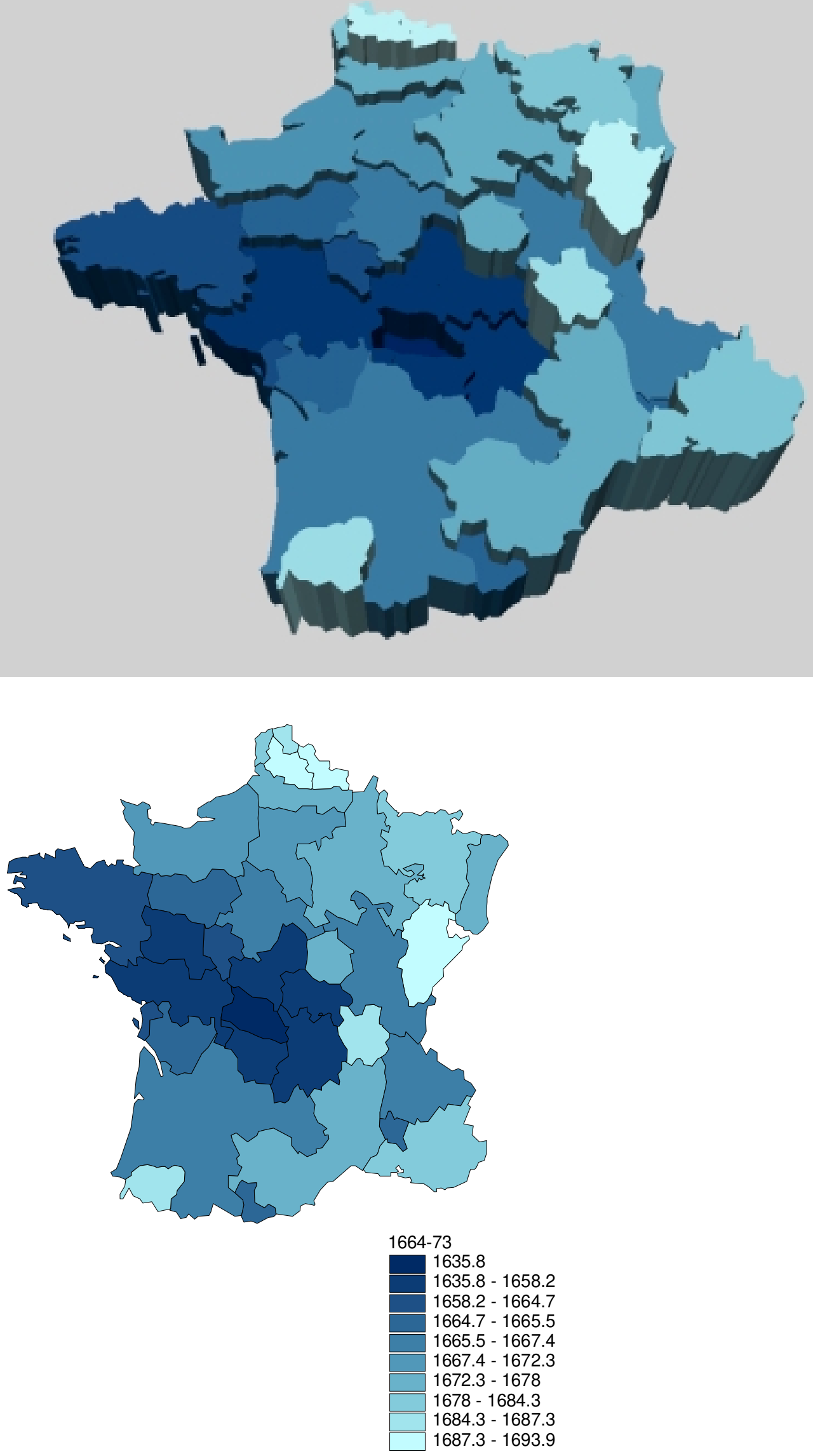
Map. 2 Adult Heights in the $17^{\text {th }}$ century (until 1694)

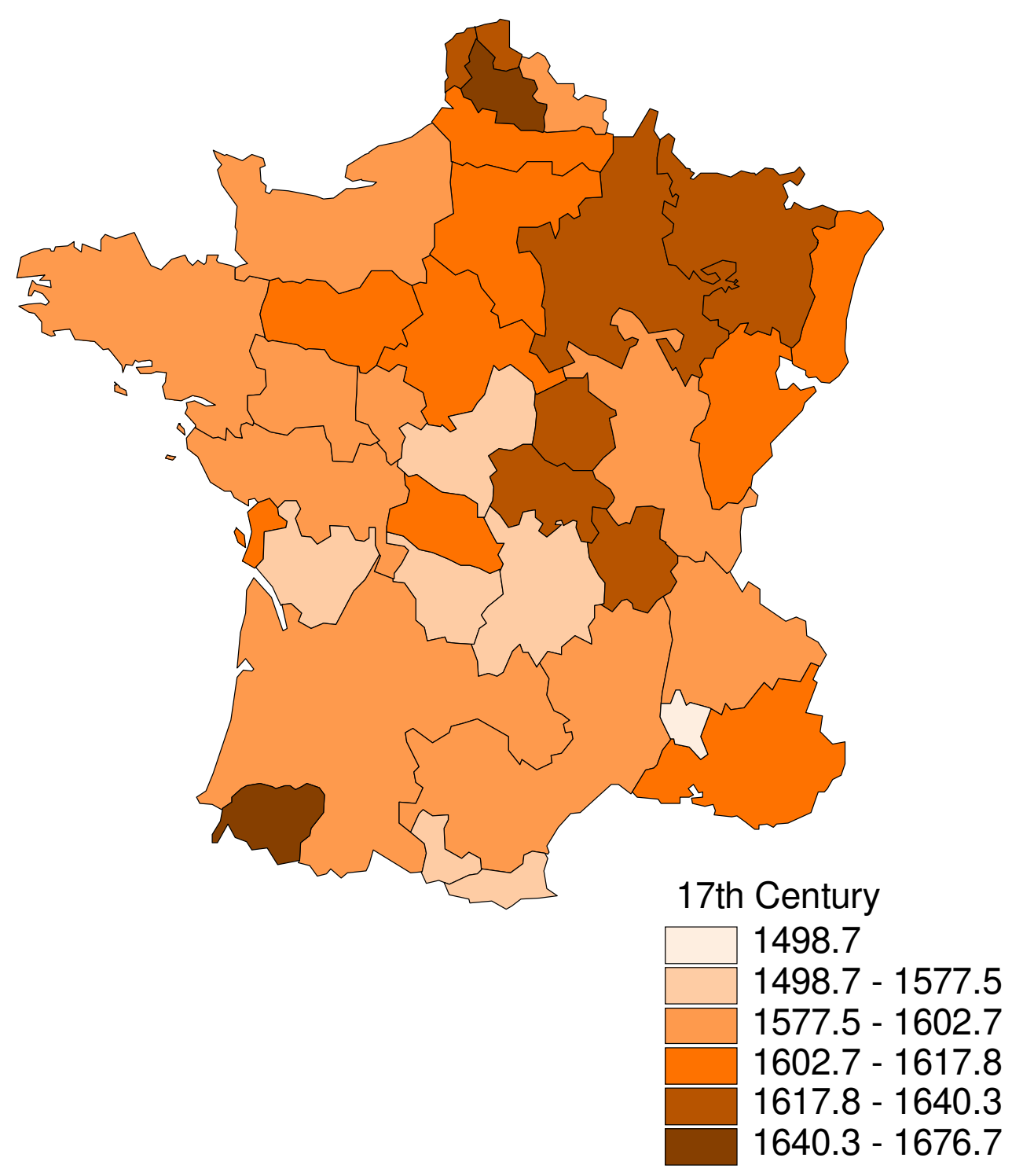



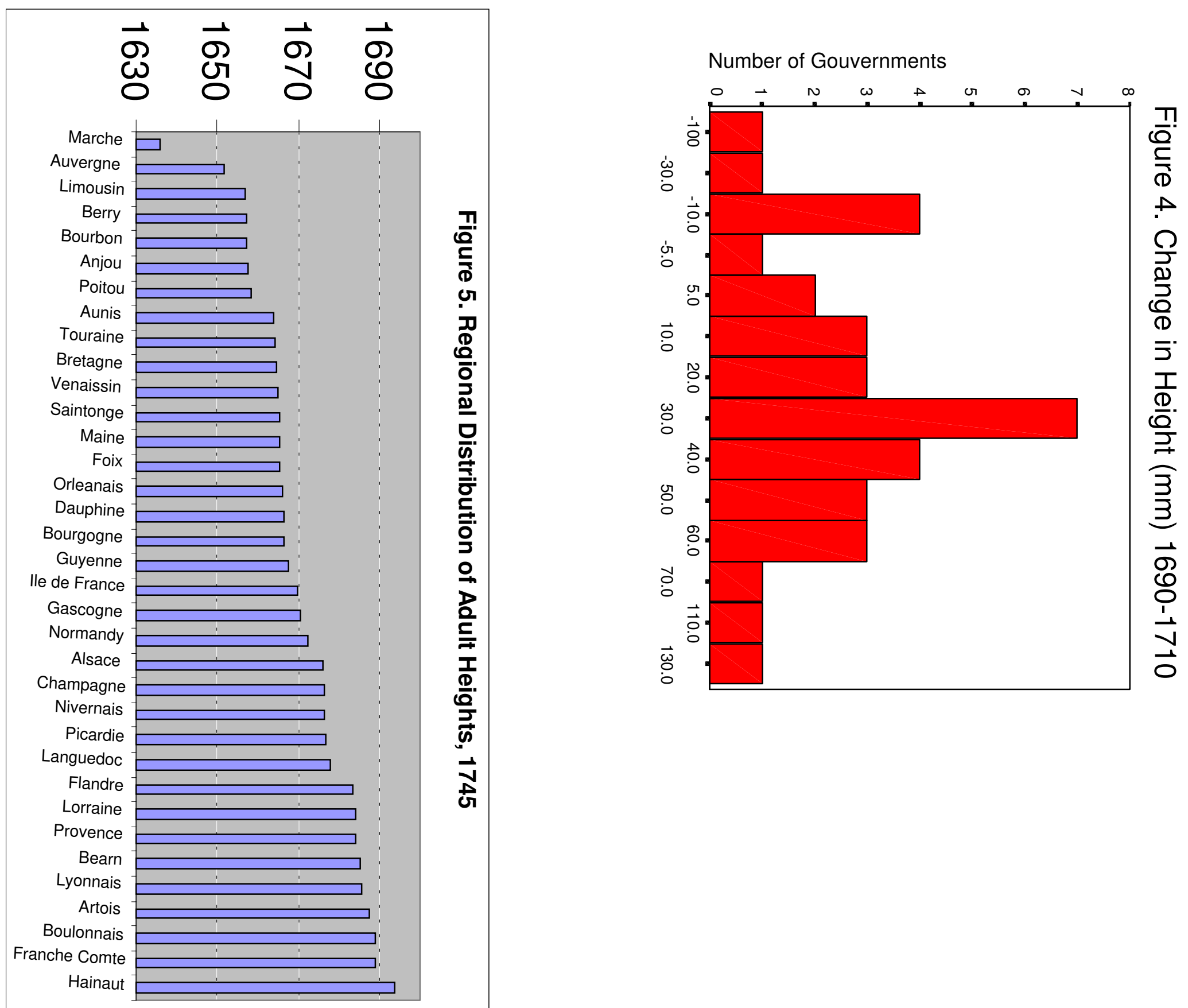

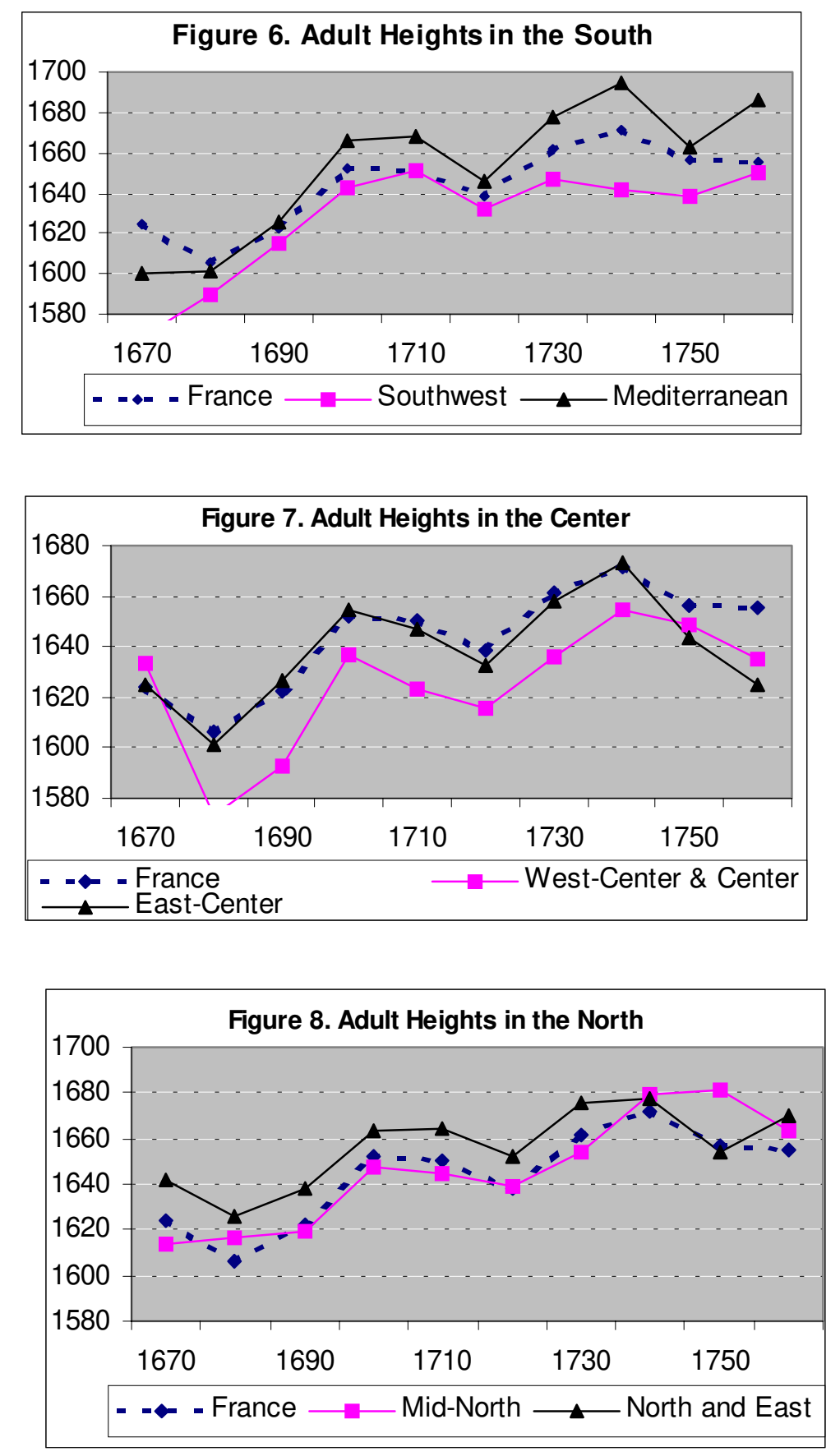

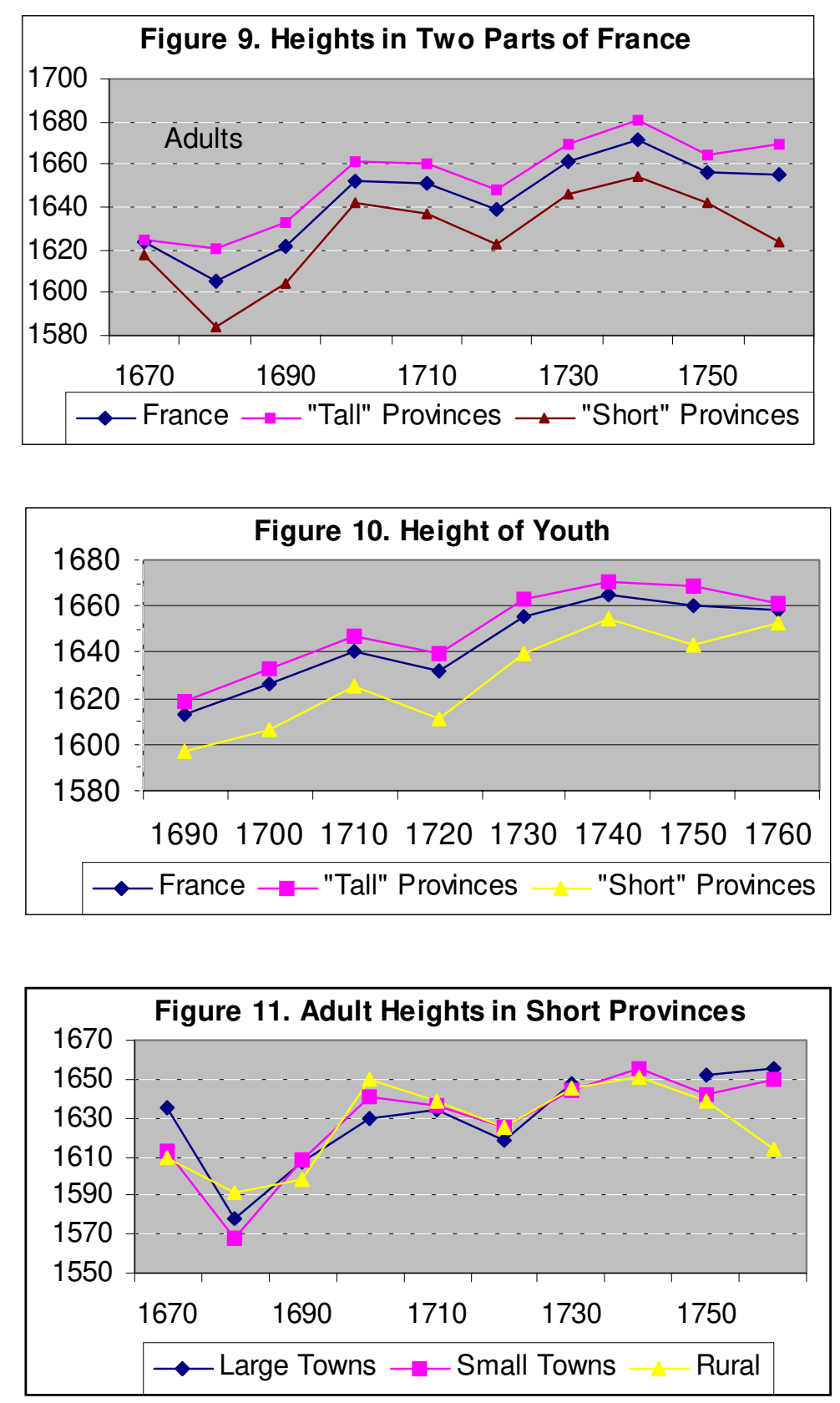

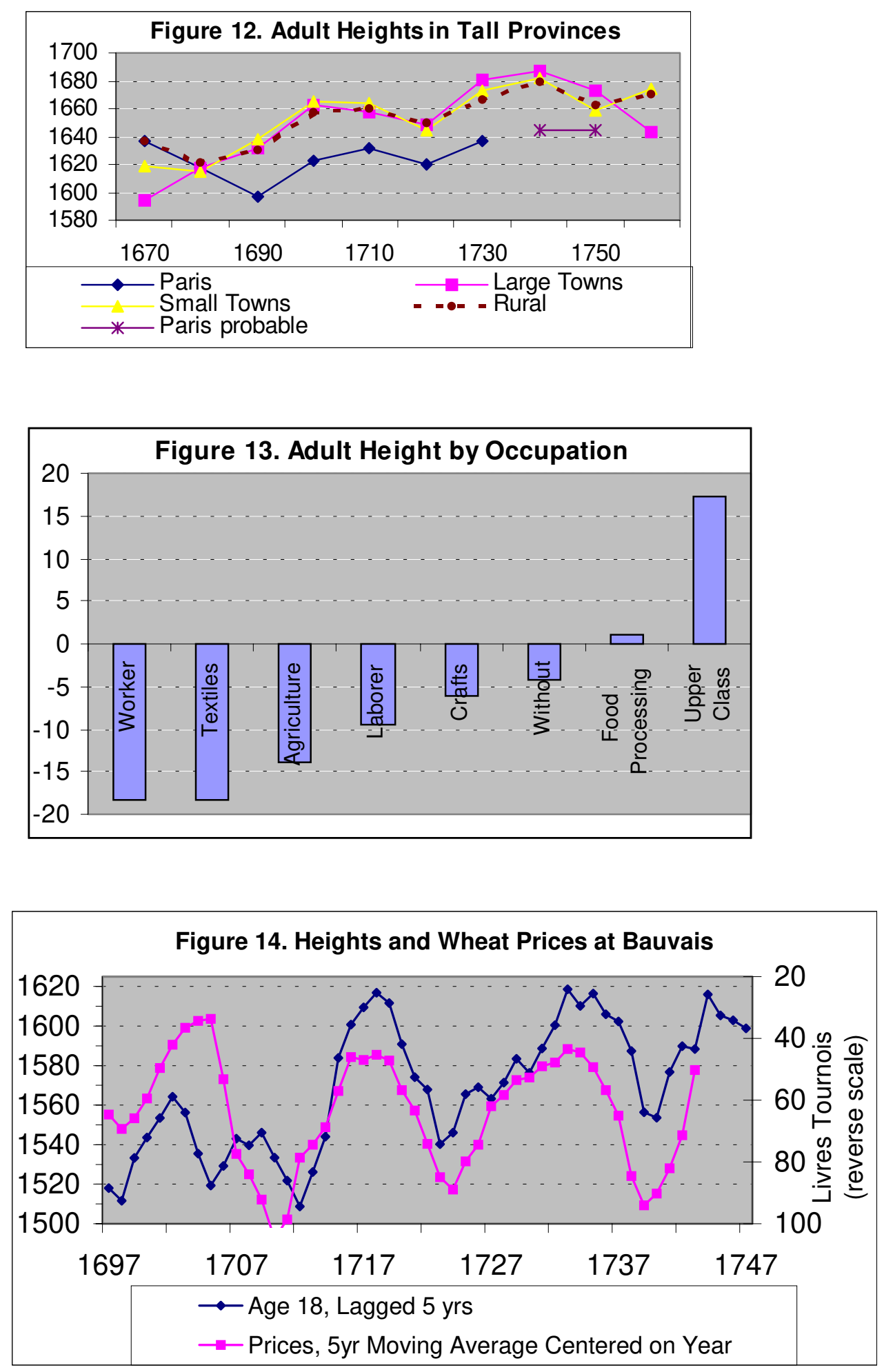

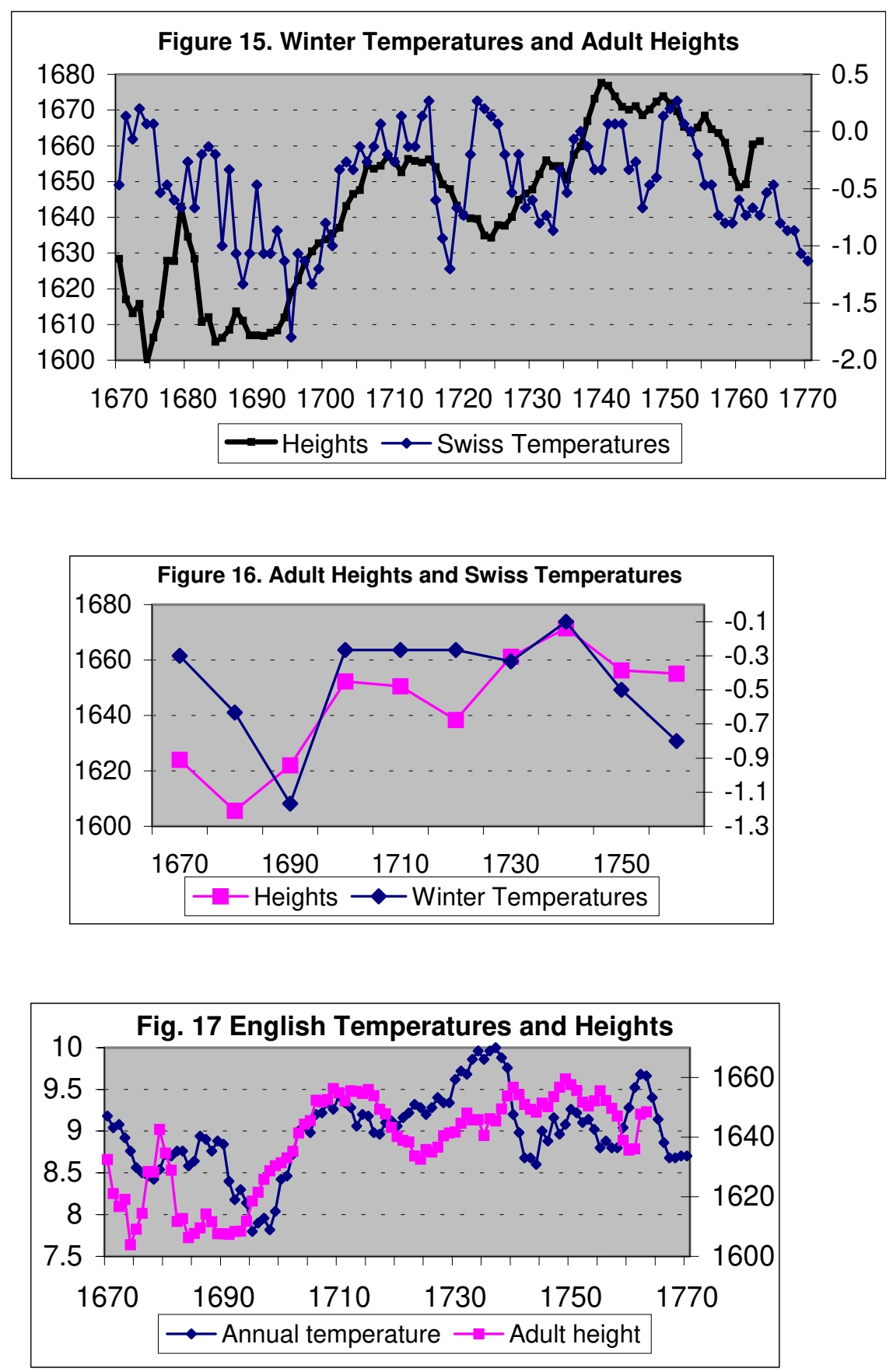

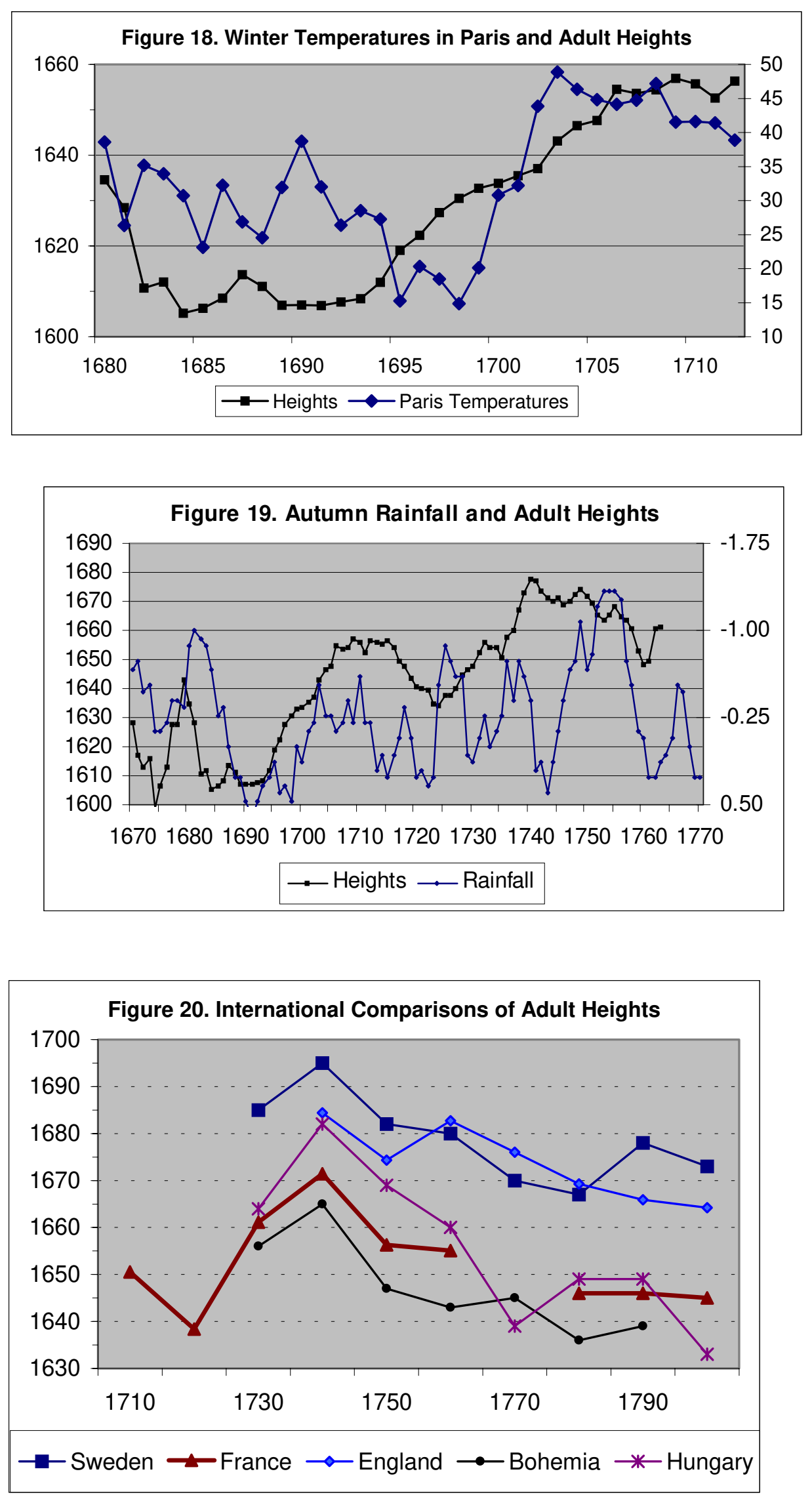


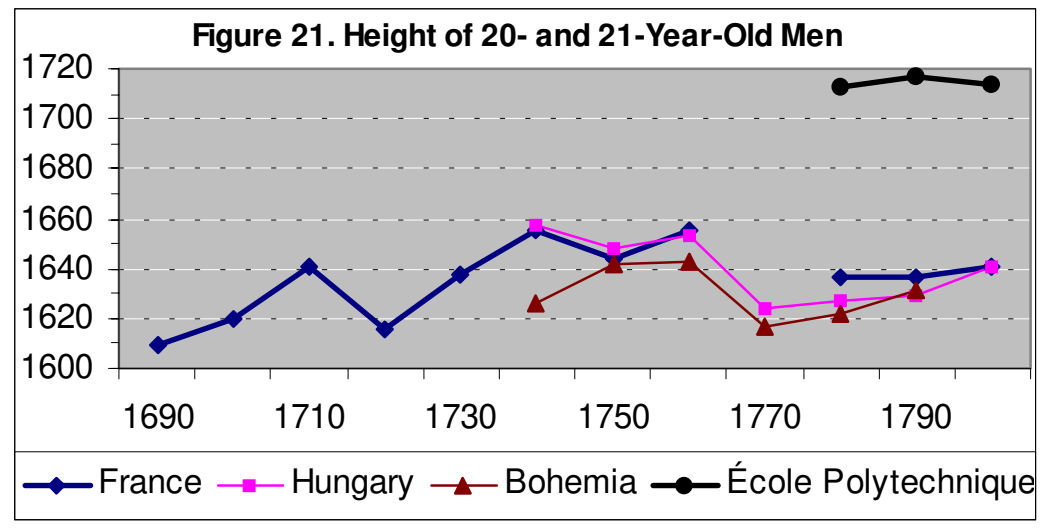

Table 1. Characteristics of the sample

Age Distribution of the soldiers

Age percent

$<16 \quad 0.1$

$16-19 \quad 26.6$

$20-24 \quad 31.3$

$25-29 \quad 18.5$

30-34 10.1

35-39 $\quad 5.8$

40-49 5.7

50-59 $\quad 1.6$

$>59 \quad 0.2$

Distribution of Father's occupation

Unknown or

Percent

not recorded

Agriculture

85,7

Worker

1,3

Textiles

Skilled

1,5

Craftsmen

1,5

0,1

Rich peasant

3,4

food

0,1

0,9

occupations

Labourer

3,4

middle class

1,8

upper class

0,3

Total

100,0

Soldiers' Occupation

$\begin{array}{lrr}\text { agriculture } & 136 & 6.5 \\ \text { worker } & 98 & 4.7 \\ \text { textiles } & 268 & 12.9 \\ \text { craftsmen } & 919 & 44.1 \\ \text { rich peasant } & 1 & 0.0\end{array}$




$\begin{array}{lrr}\text { food processing } & 146 & 7.0 \\ \text { labourer } & 239 & 11.5 \\ \text { middle class } & 139 & 6.7 \\ \text { without } & 137 & 6.6 \\ \text { Total } & 2083 & 100.0\end{array}$

$\begin{array}{rrr} & \text { Birth } & \begin{array}{c}\text { Enlistment } \\ \text { Decades } \\ \text { Percent } \\ \text { Pecades } \\ 1660\end{array} \\ 1670 & 0,9 & \\ 1680 & 2,1 & \\ 1690 & 5,8 & \\ 1700 & 12,8 & 1,3 \\ 1710 & 13,0 & 2,7 \\ 1720 & 16,7 & 18,0 \\ 1730 & 17,9 & 9,5 \\ 1740 & 12,7 & 14,9 \\ 1750 & 6,5 & 24,3 \\ 1760 & 5,8 & 12,5 \\ 1770 & 5,8 & 6,7 \\ 1780 & & 5,6 \\ \text { Total } & & 4,4 \\ \text { The } & 100,0 & 100,0\end{array}$

The first decades shown are open ended.

Place of Birth by

Gouvernements

$\begin{array}{lrr}\text { Unknown } & 2034 & 5,3 \\ \text { Alsace } & 413 & 1,1 \\ \text { Anjou } & 684 & 1,8 \\ \text { Artois } & 861 & 2,2 \\ \text { Aunis } & 95 & 0,2 \\ \text { Auvergne } & 725 & 1,9 \\ \text { Bearn } & 94 & 0,2 \\ \text { Berry } & 429 & 1,1 \\ \text { Boulonnaise } & 115 & 0,3 \\ \text { Bourbonnais } & 465 & 1,2 \\ \text { Bourgogne } & 2229 & 5,8 \\ \text { Bretagne } & 1335 & 3,4 \\ \text { Champagne } & 2198 & 5,7 \\ \text { Foix } & 58 & 0,1 \\ \text { Dauphine } & 937 & 2,4 \\ \text { Flandre } & 1500 & 3,9 \\ \text { Franche Comte } & 1837 & 4,7 \\ \text { Gascogne } & 563 & 1,5 \\ \text { Guyenne } & 3086 & 8,0 \\ \text { Hainaut } & 523 & 1,4 \\ \text { Ile de France } & 3225 & 8,3 \\ \text { Languedoc } & 2319 & 6,0\end{array}$




$\begin{array}{lrc}\text { Limousin } & 392 & 1,0 \\ \text { Lorraine } & 2877 & 7,4 \\ \text { Lyonnais } & 927 & 2,4 \\ \text { Maine } & 703 & 1,8 \\ \text { Marche } & 129 & 0,3 \\ \text { Nivernais } & 249 & 0,6 \\ \text { Normandie } & 2492 & 6,4 \\ \text { Orleanais } & 795 & 2,1 \\ \text { Picardie } & 1854 & 4,8 \\ \text { Poitou } & 705 & 1,8 \\ \text { Provence } & 787 & 2,0 \\ \text { Saintonge } & 525 & 1,4 \\ \text { Touraine } & 386 & 1,0 \\ \text { Roussillon } & 58 & 0,1 \\ \text { Venaissin } & 101 & 0,3 \\ \text { Total } & 38705 & 100,0\end{array}$

The twenty towns with the largest number of recruits in the sample

$\begin{array}{lr}\text { PARIS } & 1955 \\ \text { LYON } & 541 \\ \text { LILLE } & 510 \\ \text { AMIENS } & 434 \\ \text { ROUEN } & 345 \\ \text { METZ } & 295 \\ \text { BESANCON } & 281 \\ \text { MONTPELLIER } & 280 \\ \text { ANGERS } & 271 \\ \text { AGEN } & 267 \\ \text { CAMBRAI } & 259 \\ \text { PERIGUEUX } & 258 \\ \text { VESOUL } & 244 \\ \text { LE MANS } & 243 \\ \text { DIJON } & 231 \\ \text { ORLEANS } & 231 \\ \text { NANCY } & 224 \\ \text { REIMS } & 222 \\ \text { ARRAS } & 210 \\ \text { RENNES } & 210\end{array}$

Table 2. Heights recorded more accurately than half pouce (F.i.) .

Enlistment dates Percent

$\begin{array}{rr}-1719 & 3.0 \\ 1720-1739 & 9.0 \\ 1740-1749 & 15.0 \\ 1750-1769 & 23.0 \\ 1770-1786 & 17.0\end{array}$

Table 3. Differences in height $(\mathrm{mm})$ by enlistment decades. Standard: $1730 \mathrm{~s}^{60}$ Enlistement

Dates

Adults

Youth 


$\begin{array}{crcc}\text { Before } 1700 & -1.7 & & \\ 1700 \mathrm{~s} & -6.9 & * & 11.9 \\ 1710 \mathrm{~s} & -8.8 & * & 1.0 \\ 1720 \mathrm{~s} & -1.8 & & 1.6 \\ 1730 \mathrm{~s} & 0,0 & & 0,0 \\ 1740 \mathrm{~s} & -5,4 & * & -10.9 * \\ 1750 \mathrm{~s} & -4,6 & * & -15.6 * \\ 1760 \mathrm{~s} & 0,9 & & -20.2 * \\ 1770 \mathrm{~s} & 11.3 & * & -16.3 * \\ 1780 \mathrm{~s} & 14,5 & * & -25.2 *\end{array}$

Table 4. Periods of French Nutritional experience

Birth

Cohorts length Heights

1666-1694 29 extremely low level

1695-1706 12 rapid improvement

1706-1716 $11 \quad$ constant at a high level

1717-1724 8 rapidly decreasing

1725-1740 $16 \quad$ cyclical with marked upward trend

$\mathrm{mm}$

Change per

1617

annum

1655

$0.0 \mathrm{~mm}$

1655

$+3.2$

1634

0.0

1678

$-2.6$

1741-1760 $20 \quad$ rapidly decreasing

1649

$+2.7$

$-1.5$

Table 5. Regression Equation (Beta Coefficients)

Dependent Variable Height

\begin{tabular}{lcccc} 
& \multicolumn{2}{c}{ Age 18(-5) } & \multicolumn{2}{c}{ Age 18 $(0)$} \\
Bauvais & $-0.48^{*}$ & $-0.46^{*}$ & & \\
Temp Winter & $\mathbf{0 . 0 5}$ & & $\mathbf{0 . 2 1} *$ & $\mathbf{0 . 1 6}$ \\
Rain Autumn & $-\mathbf{0 . 1 5}$ & $-\mathbf{0 . 1 4}$ & & $-\mathbf{0 . 3 4} *$ \\
& & & & \\
& & & & \\
$\mathbf{N}$ & $\mathbf{4 7}$ & $\mathbf{4 7}$ & $\mathbf{6 2}$ & $\mathbf{6 2}$ \\
$\overline{\mathbf{R}}^{2}$ & & & & \\
$\mathrm{~F}$ & 0.15 & 0.17 & 0.03 & 0.13 \\
& $3.8^{*}$ & $4.1^{*}$ & $2.7^{*}$ & $5.4^{*}$
\end{tabular}

Note: Lags are in parenthesis.

Sources: Pierre Goubert, Beauvais et le Beauvaisis de 1600 à 1730. Contribution à l'histoire sociale de la France du XVIIe siècle, Paris, SEVPEN, 1960; Christian Pfister,

Wetternachhersage. 500 Jahre Klimavariationen und Naturkatastrophen 1496-1995 (Bern, Paul Haupt, 1998). 


\section{Endnotes}

$\overline{1}$ The data were published by Buffon in a supplement to his Histoire Naturelle. R. E. Scammon, "The first seriatim study of Human Growth,“ American Journal of Physical Anthropology, 10 (1927), 329-36, as cited in James M. Tanner, Growth at Adolescence $\left(2^{\text {nd }}\right.$ ed. Oxford: Blackwell, 1962) first published in 1955, p. 1.

${ }^{2}$ Louis René. Villermé, „Mémoire sur la Taille de L`Homme en France,“ㅆAnnales D’Hygiène Publique et de Médecine Légale 1 (1829): 351-397; here p. 353. He concluded that taller men tended to be healthier: "The difference is striking; where people are tall, there are very few rejections for military service even on account of ailments; where people are short, there are many rejections on medical grounds...; so the advantage seems to be entirely for the tall people." „the inhabitants of the plains in [the department of Gard], benefit from all advantages of nutrition, clothes, lodging...." He observed also that in the former department of Bouches de Le Meuse,... a rich countryside, with expanding commerce and industry, where people were well nourished and did not have to work at a young age, the average height of recruits at their $20^{\text {th }}$ birthday was $1,677 \mathrm{~m}$ in $1808-1810$, and very few were rejected for military service on account of medical disorders, or because of being shorter than the minimum height requirement (of 1,544 m). In contrast, in the former department of the Apennins, with Chiavari as a center, a poor, mountainous country, where people were undernourished and had to work very hard, the average height during the same three years was $1.56 \mathrm{~m}$, and rejections for military service was as high as 30 percent. (p. 352). Villermé, „Mémoire sur la Taille,“p. 352. See also Louis René Villermé. Tableau de l'état physique et moral d'ouvriers dans les fabriques de coton, de laine, et de soie, 1840.

${ }^{3}$ Moreover, those able to avoid military service by paying for replacements were one $\mathrm{cm}$ taller than those who actually enrolled in the military. Emmanuel Le Roy Ladurie, Bernageau, N., and Y. Pasquet. "Le Conscrit et l'ordinateur: Perspectives de recherches sur les archives 
militaires du XIXe siècle français.” Studi Storici 10 (1969):260-308; Emmanuel Le Roy Ladurie and N. Bernageau. 1971. "Etude sur un Contingent Militaire (1868), Mobilité Géographique, Délinquance et Stature, Mises en Rapport avec l'autres Aspects de la Situation des Conscrits." Annales de Démographie Historique, 1971: 311-337; Emmanuel Le Roy Ladurie, 1979. The Territory of the Historian, trans., Ben and Sian Reynolds. Chicago: University of Chicago Press; Emmanuel Le Roy Ladurie and M. Demonet. 1980. "Alphabétisation et stature: un tableau comparé." Annales ESC 35:1329-32; Aron, Jean-Paul, Paul Dumont and Le Roy Ladurie, Emmanuel, Anthropologie du Conscrit Français. Paris 1972.

${ }^{4}$ Michel Alexander van Meerten, 1990. Développement Économique et Stature en France, XIXe-XXe Siècles. Annales ESC (May-June), pp. 755-777; David R. Weir, „Parental Consumption Decisions and Child Health During the Early French Fertility Decline, 17901914,“ Journal of Economic History 53-2 (1993), S. 259-274; John Komlos, 1994, "The Nutritional Status of French Students," Journal of Interdisciplinary History 24, no. 3:493-508; David Weir, "Economic Welfare and Physical Well-Being in France, 1750-1990,“ In Richard Steckel and Roderick Floud, Health and Welfare during Industrialization (Chicago: The University of Chicago Press, 1997), pp. 161-200.

${ }^{5}$ French Military Archive, Chateau de Vincennes, Paris.

${ }^{6} 1$ Pied $=12$ Pouce; 1 Pouce $=12$ Lignes. 1 Pouce $=2,706667 \mathrm{~cm}$.

${ }^{7}$ In 1177 cases the province of origin was designated merely as Comte. Although one could presume that Franche Comte was meant in most of these cases, we attempted to identify the villages or towns as actually belonging to Franche Comte. Of the 959 such localities, 347 were actually found to be in Franche Comte, and they were changed accordingly. The others were included in the unknown province-of-birth category. In addition, more than a thousand records on men born outside of France were eliminated from the sample. 
${ }^{8}$ For purposes of calculating the date of birth, it is crucial to note, that the age of the soldier pertains to the date at which the registers were created. However, after the registers were begun, new recruits were continually added to the registers. For these new entrants, the age pertains to their date of enlistment, and not to when the registers were started. In other words, if the date of enlistment preceded the date at which the registers commenced, then age is as of the latter date, but if the date of enlistment is after the date of the creation of the register, then age is as of the date of enlistment. I am indebted to M. André Corvisier for this explanation.

Some 899 recruits were supposedly younger than 14 years old at the time of recruitment. These enlistment dates (grouped in a few recruiting books) were presumed incorrect and these data were not used in the part of the analysis in which enlistment dates were included as explanatory variables, but the records were not discarded, because the trend in the height in this group followed the French average, and consequently, the other data of these records were presumed to be correct.

${ }^{9}$ The signatures are: $2,5,6,7,11,13,14,15,18,21,24,25,27,30,32,35,36,41,43,44,45$, $288,356,357,358,364,370,378,383,386,380,394,395,399,404,421,433,443,451,456$, $458,462,463,472,477,478,479,485,486,487,495,496,502,506,509,513,514,518,525$, $527,528,537,539,544,551,552,559,560,568,575,579,582,588,595,601,606,608,626$, 635, 636. Numbers correspond to those listed in André Corvisier, Les Contrôles de Troupes de L'Ancien Régime Vol 2, Contrôles des Troupes Conservés aux Archives de la Guerre. Infanterie. Ministère des Armées, Etat-Major de L'Armée de Terre, Service Historique, 1970. ${ }^{10}$ These are underestimates of the available information, since we did not record father's occupation in all cases.

${ }^{11} 3.5$ million out of a total of 24.6 million. 
${ }^{12}$ Markus Heintel, „Historical Height Samples with Shortfall. A Computational Approach,“ History \& Computing, 8 (1996), 24-37; C. Cheung and A. Goldberger, „Proportional Projections in limited Dependent Variable Models, “ Econometrica 52 (1984), 531-34. ${ }^{13}$ We converted the height of the soldiers into mean population heights of French men as follows. We assume that the standard deviation of $68,58 \mathrm{~mm}$ for modern populations also held in $18^{\text {th }}$ century France. We presume, furthermore, that the truncation point was not at the MHR of 62 F.i. (1678.1 mm) but at 61.75 F.i., $(1671.4 \mathrm{~mm})$ because we assume that those recruits who were slightly below the MHR were probably allowed to slip through by having their height measurement rounded up to the nearest whole inch. (This assumption increases our estimated population means by about $1 \mathrm{~cm}$.) We take a normal distribution with mean 1700 and s.d. of $68.58 \mathrm{~mm}$ and discard all observations below $1671.4 \mathrm{~mm}$. We then calculate the mean of the truncated distribution and obtain $1738 \mathrm{~mm}$. That is, if the mean of the soldiers' height above the MHR was $1738 \mathrm{~mm}$, then the height of men from which the soldiers were drawn was $1700 \mathrm{~mm}$. In this manner we obtained the following schedule: Mean of Truncated Mean of whole
Distribution
Distribution

$\begin{array}{ll}1738 & 1700 \\ 1733 & 1690 \\ 1729 & 1680 \\ 1726 & 1670 \\ 1722 & 1660 \\ 1719 & 1650 \\ 1716 & 1640 \\ 1713 & 1630 \\ 1711 & 1620 \\ 1709 & 1610 \\ 1707 & 1600\end{array}$

We used this schedule to obtain our estimates of the height of the French male population from the calculated truncated means.

${ }^{14}$ According to Corvisier, the MHR became 62 F.i. in 1763. André Corvisier, L'Armee Française de la fin du XVIIe siècle au ministère de Choiseul. Le Soldat. Université de Paris, 
Faculté des Lettres et sciences humaines, 1964, p. 639. However, this MHR was obviously also in effect before 1740, the outbreak of the war of Austrian Succession, when it was lowered to 60 F.i. (1624 mm). In our data set, of those recruited during the War of Austrian Succession and the Seven-Years War (1740 - 1763), 37 percent were shorter than 62 F.i., while before and after this period the share was substantially lower at 22,3 and 22.5 percent respectively. After 1763, 75,6 percent of the soldiers below the MHR were 20 years old or younger, whereas during the wars only 50.5 percent were 20 or younger, and of those enlisted before 174035.3 percent were 20 or younger.

${ }^{15}$ The assumed rounding procedure increases the estimates by about one $\mathrm{cm}$ throughout without affecting their cyclical nature. The accuracy of measurements improved generally over time, insofar as the number of observations reporting heights more accurately than to half-inch intervals increased during the course of the century from three to 17 percent (Table 2).

${ }^{16}$ Adults $\mathrm{N}=15,786$; and youth (age 16-22) $\mathrm{N}=12,378$.

${ }^{17}$ Other such companies were those designated mestre (flag bearers), and as colonelle (registers 14, 18, 30,41, 477, and 496) and as lieut. colonelle (registers 18, 496). Their average height was about $174.6 \mathrm{~cm}$ as compared to the average of $169.1 \mathrm{~cm}$ for all recruits. ${ }^{18}$ The distribution of heights was investigated also by battalions in order to ascertain if there were some anomalies in recruitment across army units. We find that soldiers in battalions 1 and 4 (after the birth cohorts of the 1720s) were markedly taller than those in the other battalions. The height distributions of adult soldiers recruited after 1762 in these two battalions indicate that 29 percent of the soldiers were taller than 64.5 F.i. $(174.6 \mathrm{~cm})$ compared to 18 percent in the other battalions even if the grenadiers were excluded from the sample. Perhaps not all the grenadier units were identified in these battalions, or perhaps these became special-purpose battalions, so that taller soldiers were assigned to them. That they 
also had a much larger proportion of grenadiers (19\% v.s. $10 \%$ in the other battalions) suggests that they could well have been special-purpose units. This is particularly the case since among those recruited after 1762 in battalions 1 and 4 fully 29 percent of the soldiers were in grenadier units, whereas there were none in the sample from the other battalions after 1762. Obviously, the grenadiers were not distributed evenly among the army battalions. The height of grenadiers enlisted before 1762 was $174.7 \mathrm{~cm}$ in battalion 1 and 174.3 in the other battalions. Hence, there was not much discrimination across army units for grenadiers prior to 1762. Thereafter, only battalions 1 and 4 had grenadiers in our sample, an indication that our sampling procedure did not apply randomly across all army units. The mean raw height of grenadiers enlisted after 1762 is $176.9 \mathrm{~cm}$.

${ }^{19}$ If, for example, recruits had been measured with boots at the outset, and without boots thereafter, the recorded heights would have declined by some $1-2 \mathrm{~cm}$, rather than increase toward the end of the period. So that such an effect cannot account for an increase in height, because it is not likely that soldiers would have been measured without boots at first and then with their boots on. Moreover, there were only 329 observations on adults recruited in the 1780 s and 593 on those recruited in the 1770s.

${ }^{20}$ Dummy variables were included for the province of birth as well as for grenadiers so that fluctuations in the share of grenadiers in the sample would not influence the cycles in our estimates. On average, grenadiers were $34.6 \mathrm{~mm}$ taller than soldiers in other companies, and they made up 12 percent of the adult sample. However, insofar as grenadiers were also recruited from the general population, the level of the (pre-adjusted) estimated height of the population was increased by $4.15 \mathrm{~mm}$.

${ }^{21}$ There are 1,495 observations in the sample prior to 1685 , so that this result is based on sufficient evidence. 
${ }^{22}$ Pattern does not change meaningfully if enlistment effects are controlled for. We also did a TOLS regression for the enlistment period 1740-1763 separately with the truncation point set at 60 F.i., as the MHR was lowered to that level. The obtained trend for the birth cohorts of 1706 to 1740 was very close to the ones obtained with the 62 F.i. MHR. (The correlation coefficient between the two estimates is 0.79 and is significant at the 1 percent level.) As a consequence, there is no reason to consider separately those who enlisted between 1740 and 1763. The grenadiers were excluded from this regression. However, the pattern among the grenadiers is similar to those of the ordinary soldiers: the grenadiers' height increased from $1722 \mathrm{~mm}$ in the $1660 \mathrm{~s}$ to $1762 \mathrm{~mm}$ in the $1730 \mathrm{~s}$ and then declined thereafter to $1754 \mathrm{~mm}$ in the 1760 s.

${ }^{23} \rho=0.88(\mathrm{p}<.000)$.

${ }^{24}$ Note, that for a particular birth cohort, adults had several years of additional nutritional experience beyond those of youth. As an example, consider that the cumulative nutritional status of a hypothetical 18-year-old born in 1700 is determined between 1700 to 1718 , while the relevant period for a 23 -year-old born in the same year, is $1700-1723$. Hence, they do not overlap between 1719 and 1723 . If these years were exceptionally adverse, then the 23 -yearolds born in 1700 might well show a decline in height compared to 23-year-olds born, say, in 1695, who would not have experienced the bad years of 1719-23. Yet, 18-year-olds born in 1700 and in 1695 could well have the same height. Moreover, 18-year-olds born in 1701-1705 lived through 1719-23, so that the decline in height that first appeared among 23-year-olds born in 1700 might well become noticeable among 18 -year-olds born a year later. Such cohort effects imply that the height of youth and that of adults need not show identical trends when considered by birth cohorts. In addition, rounding the age on even numbers might well have also contributed to inaccurate estimates among the youth. Consider that the number of observations in the working data set tends to be greater among even than among odd ages. 
Age $\quad \mathrm{N}$

$18 \quad 2,043$

$19 \quad 1,892$

$20 \quad 2,030$

$21 \quad 1,534$

$22 \quad 1,959$

${ }^{25}$ In the latter period the difference is due to the unusually large number of grenadiers in the adult sample. While the share of grenadiers in the adult sample was on average 1.2 times as high as the share among the youth (10.2 v.s. 8.4), in this quinquennium the share among the adults was 1.7 (25.2\% v.s. $14.7 \%$ ) times as high as among the youth. However, the fluctuating share of the grenadiers is not the cause of the variation in the two series in the 1705 quinquiennium.

${ }^{26}$ We disregard the estimate for Marche as an outlier.

${ }^{27}$ Includes Guyenne, Gascogne, Bearn, and Comte de Foix.

${ }^{28}$ Includes Languedoc, Roussillon, Provence.

${ }^{29}$ Includes Saintonge, Aunis, Poitou, Anjou, Touraine, Orleanais, Maine, Bretagne.

${ }^{30}$ Includes Auvergne, Limousin, Marche, Bourbonnais, Berri.

${ }^{31}$ Includes Lyonnais, Nivernais, and Bourgogne.

${ }^{32}$ Includes soldiers whose birthplace was designated as „Comte“ but who could not be identified as having been definitely born in Franche-Comte. Their height was actually very close to those born in Franche-Comte, and could be presumed that most of those were actually born there. For the purposes of this analysis soldiers born in Dauphiné and Venaissin were put in the „short" provinces, and those born in Lyonnais were put into the "tall" ones.

${ }^{33}$ However, in the 1760 s the cleavage appears to have doubled between the two parts of France. Because the number of observations is very small for this birth cohort $(\mathrm{N}=87$ for "short" and N=166 for "tall" provinces), this result must be considered tentative.

${ }^{34}$ Paul Bairoch, J. Batou, and P. Chèvre, La population des villes européennes de 800 à 1850 : banque de données et analyse sommaire des résultats. The population of European cities from 
800 to 1850: Data bank and short summary of results, Centre d'Histoire économique internationale, Genève, Droz, 1988.

${ }^{35}$ An exception to this generalization is that the coefficient of the log town variable in the whole adult data set was, though small, almost significant $(\mathrm{p}=.11)$. This was probably caused by the men born in Paris.

${ }^{36}$ Small towns had between 1-9,999 inhabitants, and large towns between 10-100,000 inhabitants in 1700 .

${ }^{37}$ Heights improve substantially after 1740 , but this is unreliable and is not depicted in the diagram (Figure 12), on account of the fact that there are only a small number of observations on recruits from Paris after $1740(\mathrm{~N}=78)$ and these were not distributed randomly among the various battalions: more than half of them were from battalion 1 which had an the unusually large number of tall recruits. Hence, it is more likely that the height of the Parisians did not change substantially toward the end of the period under consideration. The height depicted for soldiers born in Paris in the 1740s and 1750s (Figure 12) reflect the height of soldiers engaged in units other than battalion 1 .

${ }^{38}$ If occupation was unavailable, the record was excluded from this part of the analysis. The occupation ,without“ (Figure 13) refers to those who gave their occupation as such, and not those for whom the information was unavailable.

${ }^{39}$ Upper class included military officers, cavalier, chevalier, gentilhomme,

${ }^{40}$ William R. Leonard, “Climatic influences on human energy metabolism,” American Journal of Human Biology, 12 (March/April 2000) 2, 298. 
${ }^{41}$ Land rents seem to correlate reasonably well with the height series. Emmanuel Le Roy Ladurie and Joseph Goy, Tithe and Agrarian History from the Fourteenth to the Nineteenth Centuries. An essay in comparative History (Cambridge University Press, 1982), p. 38.

${ }^{42}$ Jörg Baten, Ernährung und wirtschaftliche Entwicklung in Bayern (1730-1880) (Stuttgart, Franz Steiner 1999), p. 70.

${ }^{43} \rho=-0.43(p=0.01)$.

${ }^{44}$ Ulrich Woitek, ,Height Cycles in the $18^{\text {th }}$ and $19^{\text {th }}$ Centuries, “ Discussion paper in Economics No. 9811, University of Glasgow, 1998.

${ }^{45}$ Data are from Christian Pfister in collaboration with Daniel Brändli, "Raum-zeitliche Rekonstruktion von Witterungsanomalien und Naturkatastrophen 1496-1995; Schlussbericht zum Projekt 4031-33198 des NFP 31”. Zürich, Unpublished manuscript. I thank Christian Pfister for making the weather file available to me. Christian Pfister, Wetternachhersage. 500 Jahre Klimavariationen und Naturkatastrophen 1496-1995 (Bern, Paul Haupt, 1998).

${ }^{46}$ For the English annual temperatures $\rho=+0.52$, significant at the $1 \%$ level (five-year moving averages were correlated). Gordon Manley, „Central England temperatures: monthly means 1659 to 1973 , “Quarterly Journal of the Royal Meteorological Society, 100 (1974), $389-405$.

${ }^{47}$ One might also infer on the basis of these results that the weather patterns were quite uniform in this part of Europe, not only during the so-called Little Ice Age, but in the $18^{\text {th }}$ century as well.

${ }^{48}$ Jean-Pierre Legrand, and Maxime Le Goff, "Les observations météorologiques de Louis Morin,” Monographie, Nr.6, 2 Vols. (Trappes Direction de la Meteorologie Nationale Météo France, 1992). Christian Pfister and W. Bareiss, „The climate in Paris between 1675 and 1715 according to the Meteorological Journal of Louis Morin, “ in Burkhard Frenzel, Christian Pfister, and Birgit Gläser (eds.), Climatic Trends and Anomalies in Europe 1675- 
1715 (Stuttgart: Gustav Fischer, 1994), pp. 151-171. I am indebted to Christian Pfister for graciously making these records available to me.

${ }^{49}$ Summer rain beats down the wheat and makes it rot. Emmanuel Le Roy Ladurie, Times of Feast, Times of Famine: A history of Climate since the Year 1000. London, George Allen and Unwin, 1972, p. 289.

${ }^{50}$ There were frequent demographic crises in $17^{\text {th }}$ century France, "notably in 1630,1650 , 1662, and 1710. During the eighteenth century, the crises became less and less frequent, and less and less severe...“ Pierre Goubert, „Historical Demography and the Reinterpreaton of Early Modern French History: A Research Review,“ Journal of Interdisciplinary History 1 (1970): 37-48; here p. 38. 
${ }^{51}$ Some argue that the crisis of the $17^{\text {th }}$ century was essentially of climatic origin. Gustaf Utterström, "Climatic fluctuations and Population problems in early modern History," Scandinavian Economic History Review 1955, esp. p. 10.

${ }^{52}$ Markus Heintel, Lars Sandberg and Richard Steckel, ,Swedish Historical Heights Revisited: New Estimation Techniqes and Results,“ in John Komlos and Jörg Baten (eds.), The Biological Standard of Living in Comparative Perspectives: Proceedings of a Conference Held in Munich January 18-23, 1997, Stuttgart: Franz Steiner Verlag, 1998, p. 449-458; "Stature and Nutrition in the Habsburg Monarchy: The Standard of Living and Economic Development," American Historical Review 90 (1985): 1149-1161; John Komlos, "On the Nature of the Malthusian Threat in the Eighteenth Century," Economic History Review 52, no. 2 (Nov. 1999): 730-48.

53 Jörg Baten, Ernährung und wirtschaftliche Entwicklung in Bayern (1730-1880) (Stuttgart, Franz Steiner 1999); Brian A'Hearn, “On the Height of Italian Soldiers in the late- $18^{\text {th }}$ and early $19^{\text {th }}$ centuries," Unpublished Manuscript, Franklin and Marshall College.

${ }^{54}$ David Weir, Economic Welfare and Physical well-Being in France, 1750-1990,“ In Richard Steckel and Roderick Floud, Health and Welfare during Industrialization (Chicago: The University of Chicago Press, 1997), pp. 161-200, here p. 191.

${ }^{55}$ Considering enlistment cohorts, rather than birth cohorts, Corvisier noticed that heights rose initially 1716-40 (by about $4 \mathrm{~cm}$ ), and subsequently declined. He attributed this pattern to selectivity bias. He argued that average heights were lower in 1763 than in 1737 but above 1716 levels, and added that perhaps the difficulty of recruiting soldiers during the SevenYears-War contributed to the decline in height. Corvisier, L'Armée Française, p. 643. Insofar as we restrict our calculations only to those soldiers who were uniformly above the 62 F.i. MHR, we can affirm beyond a reasonable doubt that the trends obtained were due to environmental effects, and were not caused by the recruitment practices of the military. 
${ }^{56}$ Hugh. R. Trevor-Roper, The crisis of the seventeenth century; religion, the Reformation, and social change (New York, Harper \& Row, 1968).

${ }^{57}$ Le Roy Ladurie, Times of Feast, p. 90.

${ }^{58}$ Ernest Labrousse, La crise de l'économie française a la fin de l'ancien régime et au début de la révolution. Paris, Presses universitaires de France, 1944.

${ }^{59}$ Louis Cullen, «La crise économique de la fin de l'Ancien Régime,» in Jean-Pierre Poussou (ed.),

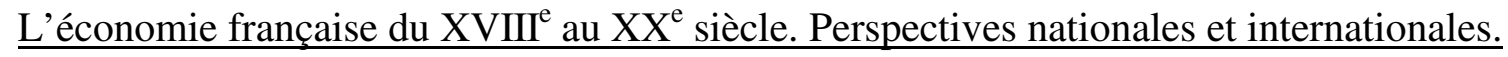
Mélanges offerts à François Crouzet (Paris: Presses de L'Université de Paris - Sorbonne, 2000, pp. 581-602; François_Crouzet, "England and France in the Eighteenth Century“, p. 154 ${ }^{60}$ The TOLS regression excluded all observations below 61.75 F.i., and also excluded those who were allegedly unborn at the time of enlistment. The differences are measured in terms of raw height estimates of the soldiers. 